\title{
Penanaman Karakter Pada Siswa Melalui Kegiatan Intrakurikuler dan Ekstrakurikuler Di Sekolah Dasar Terpadu Islam
}

\author{
Ach. Baidowi \\ STIDKI Al-Mardliyyah Pamekasan \\ Achbaidowi16@gmail.com
}

\begin{abstract}
Character education is an effort to foster and shape student character according to school culture. The research objective was to describe the process of cultivating character in students through school intracurricular and extracurricular activities. The research method with qualitative, data collection with interview, observation, and documentation. The results showed (1) character planting through intracurricular activities with (a) strengthening learning, namely character building in accordance with the theme or material, and (b) spiritual paradigm by inserting Islamic values in the learning process. (2) character planting through extracurricular activities with (a) scouts, namely forming leadership characters, being independent, solving problems, and loving nature, (b) leadership, forming leadership characters, responsibility, and making decisions, (c) painting, forming detailed, focused, creative characters, (d) martial art, forming tough, skilled characters, (e) reciting recitation, forming religious, moral, orderly characters, (f) child preachers, forming brave characters, positive thinking, art of communication, influencing others.
\end{abstract}

Keyword: Character Education; Intracurricular; Extracurricular

\begin{abstract}
Abstrak
Pendidikan karakter merupakan upaya membina dan membentuk karakter siswa sesuai dengan budaya sekolah. Tujuan penelitian untuk mendeskripsikan proses penanaman karakter siswa melalui kegiatan intrakurikuler dan ekstrakurikuler di sekolah. Metode penelitian dengan kualitatif, teknik pengumpulan data dengan wawancara, observasi, dan dokumentasi. Hasil penelitian ini menunjukkan: (1) Penanaman karakter melalui kegiatan intrakurikuler dengan cara (a) Penguatan pembelajaran yaitu pembentukan karakter yang sesuai dengan tema atau materi, dan (b) paradigma spriritual dengan menyisipkan nilai keislaman dalam proses
\end{abstract}


pembelajaran. (2) Penanaman karakter melalui kegiatan ekstrakurikuler, (a) Pramuka yaitu membentuk karakter kepemimpinan, mandiri, memecahkan masalah, dan cinta alam, (b) Kepemimpinan, membentuk karakter kepemimpinan, tanggung jawab, dan membuat keputusan, (c) Melukis, membentuk karakter detail, fokus, kreatif, (d) Pencak silat, membentuk karakter tangguh, terampil, (e) Mengaji, membentuk karakter religious, akhlak, tertib, (f) Pendakwah cilik, membentuk karakter berani, berfikir positif, seni komunikasi, mempengaruhi orang lain.

Kata Kunci: Pendidikan Karakter; Intrakurikuler; Ekstrakurikuler

\section{PENDAHULUAN}

Pendidikan adalah proses membimbing, membina, dan membentuk siswa sesuai agar memiliki pengetahuan dan kemampuan sesuai dengan tujuan sekolah, bangsa, dan negara.Usaha untuk mengembangkan dan menambah ilmu pengetahuan seseorang yang dilakukan oleh orang atau organisasi (sekolah atau perguruan tinggi) disebut pendidikan. ${ }^{1}$ Maka untuk membimbing, membina, dan membentuk siswa agar sesuai dengan tujuan pendidikan Indonesia dapat dilakukan dengan melaksanakan pendidikan karakter di setiap lembaga pendidikan.

Pendidikan diartikan sebagai proses memberi pengetahuan, sedangkan karakter diartikan sebagai watak, kebiasaan, dan sikap yang membedakan satau individu dengan individu yang lain yang terdapat pada diri seseorang. Sehingga pendidikan karakter dapat diartikan sebagai usaha yang dilakukan sekolah dalam rangka membentuk siswa agar memiliki karakter atau ciri khas berupa sikap, intelegensi, dan spiritual siswa sesuai dengan budaya sekolah agar dapat bermanfaat bagi keberlangsungan hidup siswa baik pada lingkungan sekolah, sosial masyarakat, serta bangsa dan negara.

Pelaksanaan pendidikan karakter harus sejalan dengan nilai kemusiaan, agama, dan sosial masyarakat agar dapat membentuk siswa yang memiliki kualitas yang baik berdasarkan pada potensi dan kemampuan

\footnotetext{
${ }^{1}$ Achmad Baidowi, "Implementasi Kebijakan Program Bantuan Operasional Penyelenggaraan Pendidikan Pada Masa Pandemi Covid-19”, Jambura Journal of Educational Management, Vol. 1, No. 2 (September 2020), 84-102.
} 
siswa. Pendidikan karakter dilaksanakan melalui penerapan nilai-nilai yang terdapat dalam Pancasila antara lain religius, jujur, toleransi, bekerja keras, disiplin, kreatif, mandiri, demokrasi, ingin mengetahui, berkebangsaan, cinta tanah air, komunikatif, berprestasi, gemar membaca, cinta damai, peduli lingkungan, berjiwa sosial tinggi, dan bertanggung jawab. ${ }^{2}$

Salah satu tujuan dari dilaksanakannya pendidikan karakter adalah untuk menghasilkan siswa yang memiliki nilai dan budi pekerti yang sesuai dengan budaya sekolah, budaya agama, dan budaya sosial atau lingkungan. Sehingga dapat dikatakan bahwa pendidikan karakter adalah upaya menciptakan budaya sekolah yang dapat membantu siswa dalam mengembangkan sikap, tingkah laku dan tanggung jawabnya melalui proses pembelajaran karakter dengan menanamkan karakter yang universal kepada siswa. ${ }^{3}$

Berdasarkan uaraian di atas, maka penelitian ini memiliki tujuan untuk menjelaskan bagaimana proses penanaman karakter yang dilakukan oleh sekolah melalui kegiatan intrakurikuler dan ekstrakurikuler yang ada di sekolah. Tujuan pendidikan karakter adalah mengembangkan potensi, kebiasaan, perilaku, serta kemampuan siswa agar menjadi warga negara yang baik, berakhlak mulia, memiliki jiwa kepemimpinan, agar menjadi siswa mandiri, kreatif, dan memiliki rasa nasionalime yang tinggi kepada bangsa. 4

\section{METODE PENELITIAN}

Penelitian menggunakan pendekatan kualitatif yaitu penelitian yang dilakukan untuk mendapatkan hasil penelitian pada kondisi yang alami atau natural. Penelitian kualitatif adalah teknik penelitian yang digunakan untuk

\footnotetext{
${ }^{2}$ Perpres RI Nomor 87 tahun 2017 tentang Penguatan Pendidikan Karakter

${ }^{3}$ Binti Maunah, "Implementasi Pendidikan Karakter Dalam Pembentukan Keperibadian Holistik Siswa”, Jurnal Pendidikan Karakter, Vol. V, No. 1 (2015), 90-101, [https://doi.org/10.21831/jpk.v0il.8615].

${ }^{4}$ Nopan Omeri, "Pentingnya Pendidikan Karakter Dalam Dunia Pendidikan”, Jurnal Manajer Pendidikan, Vol. 9, No. 3 (Juli 2015), 464-468.
} 
meneliti objek atau lokasi penelitian secara alami. ${ }^{5}$ Teknik pengumpulan data dilakukan dengan cara, pertama, wawancara yaitu dengan mengajukan beberapa pertanyaan kepada informan. Wawancara merupakan teknik pengambilan data yang digunakan untuk mengetahui sesuatu dari informan atau partisipan secara mendalam tentang situasi dan fenomena yang terjadi di lokasi penelitian. ${ }^{6}$ Kedua, dokumentasi yaitu dengan mengumpulkan dokumen berupa file atau berkas, foto, dan video. Dokumentasi yang dikumpulkan peneliti dapat berupa tulisan, gambar, atau karya monumental yang dikumpulkan peneliti dari sumber yang terpercaya. ${ }^{7}$ Ketiga, observasi, yaitu dengan mengamati gerak-gerik atau tingkah laku yang terjadi pada objek penelitian. Observasi yaitu mengamati suatu tindakan yang dilakukan seseorang untuk mencapai tujuan. ${ }^{8}$

Teknik Analisa data pertama kondensasi data adalah mengolah data berdasarkan hal pokok penelitian. Mengolah data dilakukan pada saat data mulai dikumpulkan dengan cara menganalisis data hasil dari penelitian. ${ }^{9}$ Kedua menyajikan data yaitu menampilkan data dalam bentuk tulisan yang ringkas, padat, dan jelas. Penyajian data dapat dilakukan dengan bentuk uraian singkat, bagan, hubungan katagori, dan sebagainya. ${ }^{10}$ Ketiga, menyimpulkan data yaitu dengan membuat kesimpulan terhadap data yang telah diolah oleh peneliti. Desain penelitian dapat digambarkan sebagai berikut:

${ }^{5}$ Sugiyono, Metode Penelitian Kuantitatif, Kualitatif, dan R\&D, (Bandung: Alfabeta, 2011), 09.

${ }^{6}$ Satori and Komariah, Metodologi Penelitian Kualitatif, (Bandung: Alfabeta, 2010), 130 .

7 Sugiyono, Metode Penelitian Pendidikan: Pendekatan Kuantitatif, Kualitatif, dan $R \& D$, (Bandung: Alfabeta, 2013), 240.

${ }^{8}$ Sugiyono, Metode penelitian kuantitatif, 226.

${ }^{9}$ Sugiyono, Metode penelitian kuantitatif, 246.

${ }^{10}$ Sugiyono, Metode penelitian kuantitatif, 249. 
Gambar 1. Desain Penelitian

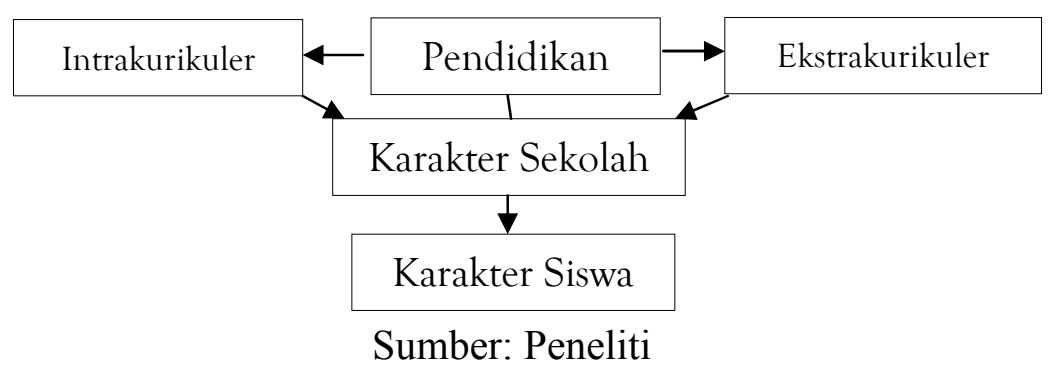

\section{HASIL DAN PEMBAHASAN TEMUAN}

Hasil penelitian tentang proses penanaman karakter pada siswa dapat ditampilkan dalam gambar berikut:

\section{Gambar 2. Diagram Proses Penenaman Karakter}

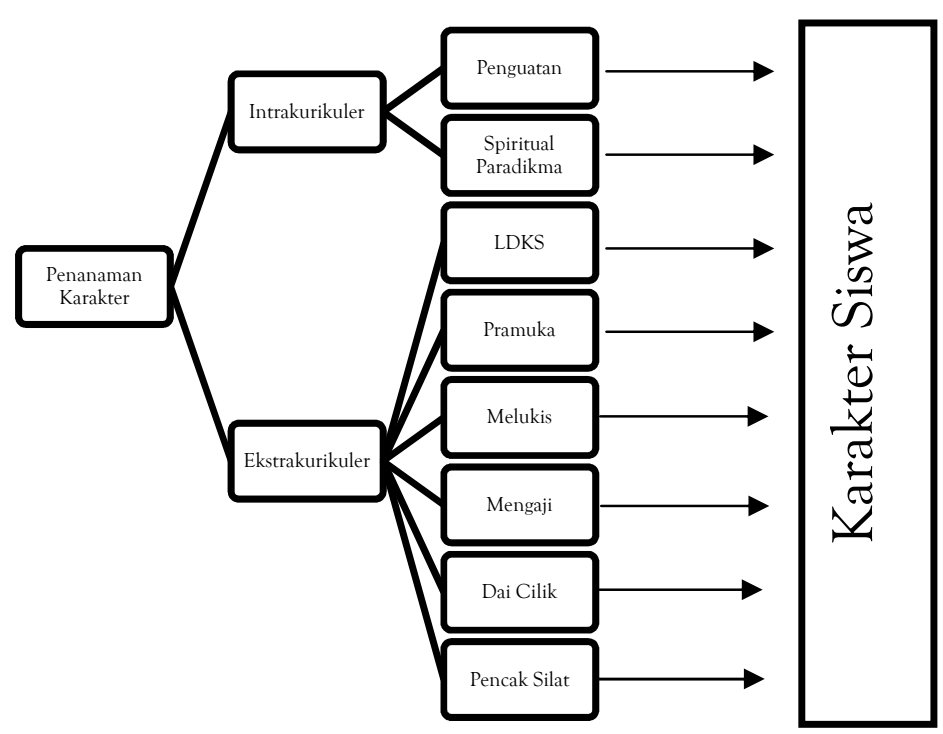

Sumber: Peneliti

Gambar diagram hasil temuan penelitian tentang penanaman karakter pada siswa melalui kegiatan intrakurikuler dan ekstrakurikuler tersebut dapat dijelaskan pada tabel temuan penelitian sebagai berikut:

Tabel 1. Temuan Penelitian

\begin{tabular}{|c|c|c|}
\hline Kegiatan & Pelaksanaan & Karakter Siswa \\
\hline Intrakurikuler & $\begin{array}{ll}\text { - } & \text { Penguatan } \\
\text { pembelajaran } \\
\text { - } & \text { Spiritual } \\
\text { paradigma }\end{array}$ & $\begin{array}{ll}\text { - } & \text { Pembentukan karakter sesuai isi } \\
\text { dan tujuan mata pelajaran (tema) } \\
\text { - } \\
\text { Penyisipan karakter Islam dalam } \\
\text { setiap mata pelajaran }\end{array}$ \\
\hline Ekstrakurikuler & LDKS & - Kepemimpinan \\
\hline
\end{tabular}




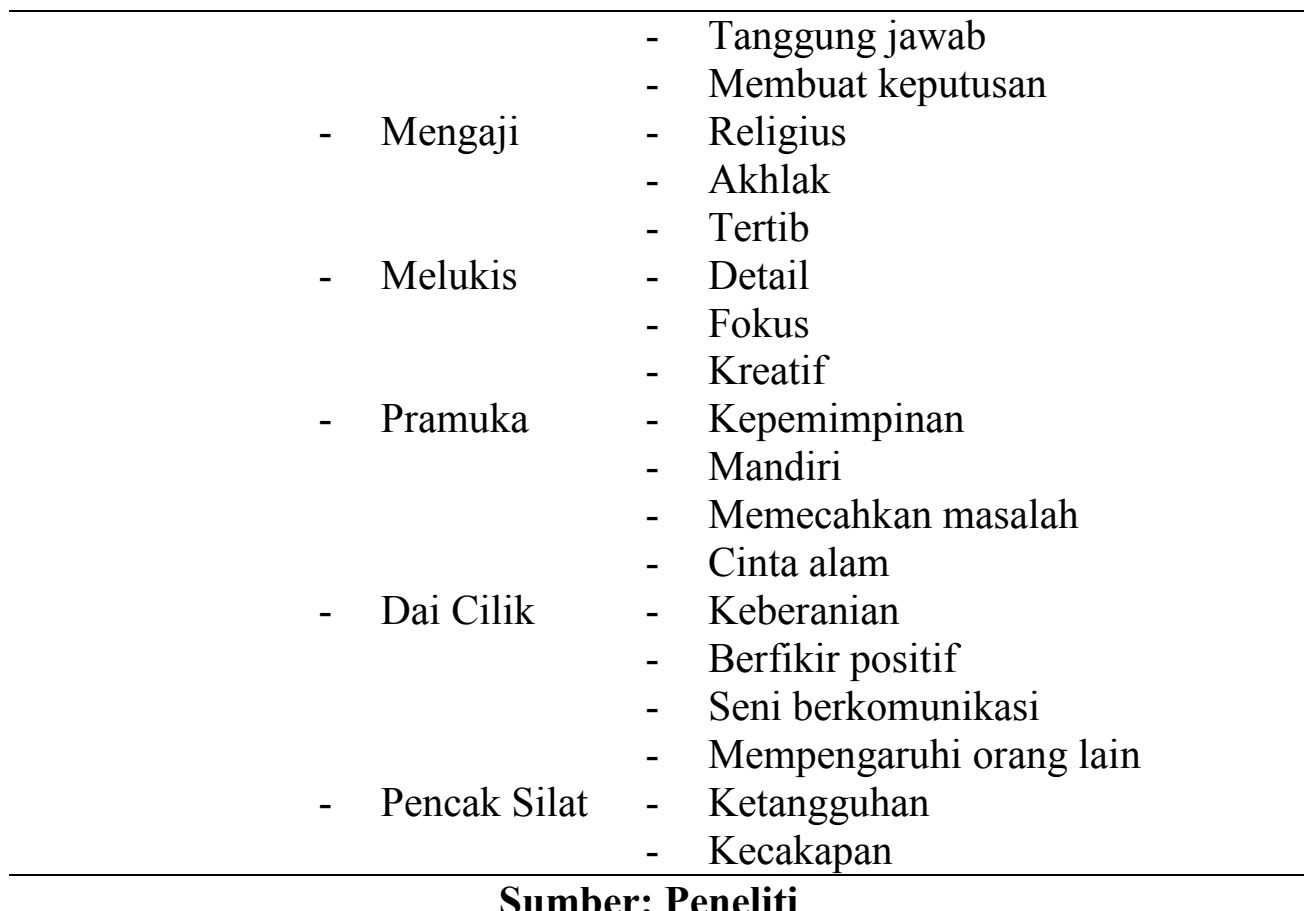

Pendidikan karakter adalah rangkaian kegiatan atau tindakan yang dilakukan secara sistematis dengan tujuan untuk membina atau membangun kepribadian seseorang (siswa) baik itu yang menyangkut aspek attitude, keterampilan, dan psikologis siswa yang dilakukan secara terus menerus oleh sekolah agar menjadi siswa yang lebih baik melalui kegiatan pengembangan diri siswa, baik yang bersifat akademis maupun nonakademis. Pembinaan karakter pada siswa dapat dilakukan melalui proses pendidikan yang dilakukan secara terprogram, bertahap, dan berkesinambungan. $^{11}$ Maka, penanaman karakter pada siswa dapat dilakukan melalui kegiatan berikut:

\section{Kegiatan Intrakurikuler}

Kegiatan intrakurikuler adalah proses pendidikan yang terjadi antara guru dan murid yang dicirikan dengan adanya kegiatan belajar mengajar di dalam kelas. Maka pendidikan karakter melalui kegiatan intrakurikuler

\footnotetext{
${ }^{11}$ Binti Maunah, "Implementasi Pendidikan Karakter Dalam Pembentukan Kepribadian Holistik Siswa”, Jurnal Pendidikan Karakter, Vol. V, No. 1 (2015), 90-101, [https://doi.org/10.21831/jpk.v0i1.8615].
} 
diartikan sebagai suatu proses penanaman karakter yang dilakukan oleh guru atau pendidik melalui kegiatan belajar mengajar yang terjadi di dalam kelas. Pendidikan karakter dapat dilakukan melalui pendekatan desain proses belajar mengajar di kelas, hal tersebut akan membentuk suatu hubungan dan komunikasi pembelajaran yang memiliki perspektif atau pandangan yang luas antara guru dan siswa dalam mendeskripsikan dan menafsirkan teori pembelajaran. ${ }^{12}$ Maka berdasarkan uraian tersebut, proses penenaman karakter dilakukan dengan dua cara sebagai berikut:

\section{Gambar 3. Penanaman Karakter Pada Kegiatan Intrakurikuler}

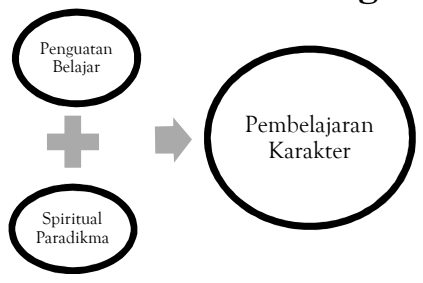

Sumber: Peneliti

\section{Penguatan Pembelajaran}

Penguatan pembelajaran dimaksudkan untuk memberi penekanan kepada siswa tentang karakter yang terdapat pada mata pelajaran yang sedang dipelajari agar terbentuk karakter yang kuat sesuai dengan teori yang diberikan. Pendidikan karakter pada kegiatan intrakurikuler dilaksanakan dengan cara mengintegrasikan seluruh bidang mata pelajaran dengan karakter organisasi. ${ }^{13}$ Misalnya, untuk membangun karakter kepekaan, kepedulian, dan toleransi pada siswa dapat dilakukan melalui mata pelajaran Pendidikan Kewarganeraan (PKn) melalui penanaman nilai dan norma kehidupan bermasyarakat, berbangsa, dan bernegara. Untuk membentuk karakter siswa cara berbahasa yang baik, santun, dan sikap yang sopan dapat dilakukan pada pelajaran bahasa Indonesia. Untuk membentuk karakter

\footnotetext{
${ }^{12}$ Kesuma, Dharma, Triatna, Cepi, dan Pramana, Johar, "Pendidikan Karakter: Kajian Teori dan Praktik di Sekolah”, (Bandung: Remaja Rosdakarya, 2011), 2.

${ }^{13}$ Binti Maunah, "Implementasi Pendidikan Karakter Dalam Pembentukan Kepribadian Holistik Siswa”, Jurnal Pendidikan Karakter, Vol. V, No. 1 (2015), 90-101, [https://doi.org/10.21831/jpk.v0il.8615].
} 
siswa yang taat dan patuh pada Tuhannya dan menghargai seluruh ciptaanNya, maka dapat dilakukan melalui pelajaran pendidikan agama. Penanaman karakter pada siswa dapat dilakukan dengan pendekatan ilmu sosial sehingga terbentuk karakter siswa yang bertanggung jawab, jujur, adil, disiplin, toleransi, integritas, dan lain sebagainya. ${ }^{14}$

\section{Paradigma Spiritual}

Paradikma spiritual merupakan penanaman karakter yang dilakukan dengan cara menyisipkan nilai-nilai keagamaan atau keislaman (Islamic values) di dalam proses belajar mengajar di kelas agar sesuai dengan karakteristik organisasi. Misalnya, pada mata pelajaran Matematika tentang berhitung, maka dalam proses pembelajaran guru akan memberikan sisipan keislaman tentang tata cara menghitung, misalnya cara menghitung zakat yang benar, menghitung jumlah rokaat dalam sholat, menghitung jumlah hari dalam bulan ramadan, dan lain sebagainya. Misalnya dalam mata pelajaran Ilmu Pengetahuan Alam bab tentang kekayaan alam Indonesia, maka dalam proses pembelajaran siswa akan diberikan pengetahuan dan pemahaman tentang tanda-tanda kebesaran Allah SWT melalui terciptanya alam dan isinya sehingga siswa memiliki keyakinan yang kuat terhadap Allah SWT. Pendidikan karakter dapat dilakukan dengan menanamkan nilai-nilai sesuai budaya sekolah kepada siswanya melalui berbagai pranata atau aturan sekolah. Tujuannya adalah agar nilai atau budaya tertentu dapat terbentuk dan tertanam pada diri masing-masing siswa sesuai lingkungan tempat siswa bersekolah. ${ }^{15}$

Implementasi kegiatan spiritual paradikma ini dilakukan melalui beberapa cara, pertama, pemilihan dalil (konsep keislaman) sesuai dengan tema. Ketika seorang guru akan memberikan pembelajaran sesuai dengan

\footnotetext{
${ }^{14}$ Badawi, "Pendidikan Karakter Dalam Pembentukan Akhlaq Mulia di Sekolah”, Ilmu $\begin{array}{llll}\text { Pendidikan, } & \text { Prosiding } & \text { SEMNASFIP, }\end{array}$ [https//journals.ums.ac.id/index.php/j[is/article/view/6710/4101].

${ }^{15}$ Kesuma, Dharma, Triatna, Cepi, dan Permana, Johar, "Pendidikan Karakter: Kajian Teori dan Prakti Di Sekolah”, (Bandung: Remaja Rosdakarya, 2011), 2.
} 
tema yang akan disampaikan, maka guru harus mendukung tema tersebut dengan dalil yang bersumber dari Al-Qur'an dan Al-Hadist. Kedua, menggunakan media alat yang belajar yang bersifat islami, misalnya bangun kubus guru dapat mencotohkan dengan menggunakan miniatur ka'bah, bentuk silinder dengan pilar masjid, dan lain sebagainya. Ketiga, menggunakan bahasa yang bersifat islami dalam setiap penjelasan teori dan soal latihan, misalnya dalam pelajaran Matematika guru menjelaskan tentang penjumlahan, maka guru dapat menjelaskan dengan menyisipkan nuasa islami dalam soal seperti "berapa jumlah kambing yang dibutuhkan untuk aqiqah 1 anak laki-laki dan 2 anak perempuan?" maka, dengan demikian akan terbentuk karakter siswa yang cinta dan paham akan agama Islam. Pendidikan karakter yang terintegrasi dengan mata pelajaran mewajibkan guru dapat menyesuaikan konsep pendidikan karakter disetiap proses pembelajaran, membuat rencana pembelajaran yang sudah terintegrasi dengan konsep karakter yang diinginkan, menggunakan perangkat pembelajaran yang dapat menunjang pemberian penanaman karakter pada proses pembelajaran, serta dapat menggunakan bahan pembelajaran yang sesuai dengan penanaman karakter yang diinginkan ${ }^{16}$.

\section{Kegiatan Ekstrakurikuler}

Ekstrakurikuler merupakan proses pendidikan yang dikhususnya untuk melatih dan mengembangkan bakat dan minat siswa diluar kemampuan akademiknya yang dilakukan di luar kegiatan intrakurikuler sekolah. Ekstrakurikuler adalah kegiatan bimbingan dan konseling terhadap bakat, minat, potensi, serta kebutuhan siswa yang dilakukan di luar jam mata pelajaran yang dilakukan oleh pendidikan atau tenaga kependidikan

\footnotetext{
16 Citra, Yulia, "Pelaksanaan Pendidikan Karakter Dalam Pembelajaran”, Jurnal Penelitian Pendidikan Khusus, Vol. 1 No. 1 (Januari 2012), 237-49, [https://doi.org/10.24036/jupe7950.64].
} 
yang ada di sekolah. ${ }^{17}$ Pendidikan karakter melalui kegiatan ekstrakurikuler diartikan sebagai usaha pembentukan dan menanamkan karakter kepada siswa melalui kegiatan pembimbingan, pembinaan, dan pengembangan bakat dan minat (potensi) siswa yang dilakukan di luar jam akademik siswa di sekolah. Kegiatan ekstrakurikuler sangat baik untuk membentuk watak siswa yang sopan, jujur, jiwa patriot (jiwa bela negara), menghargai perbedaan (toleransi), simpati terhadap sekitar dan lain sebagainya. ${ }^{18}$ Kegiatan ekstrakurikuler tersebut antara lain:

\section{Gambar 4. Penanaman Karakter Kegiatan Ekstrakurikuler}

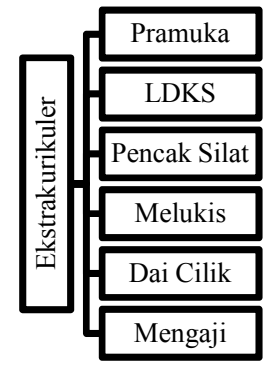

Sumber: Peneliti

\section{Pramuka}

Pramuka adalah kegiatan pendidikan yang dilakukan di luar jam sekolah dan di alam terbuka yang dilaksanakan dengan suasana menyenangkan berdasarkan pada prinsip kepramukaan. Karakter yang dibentuk pada kegiatan ektrakurikuler pramuka antara lain:

a. Kepemimpinan, ekstrakurikuler pramuka dapat melatih jiwa kepemimpinan yang ada dalam diri siswa khususnya kepemimpinan dalam organisasi sekolah. Latihan kepemimpinan dalam kegiatan pramuka adalah agar siswa dapat memiliki peran yang baik dalam kehidupan suatu organisasi yang ada di sekolah atau di masyarakat. ${ }^{19}$

\footnotetext{
${ }^{17}$ Asmani, J,Buku Panduan Internalisasi Pendidikan Karakter di Sekolah, (Yogyakarta: Diva Pers, 2011), 62.

${ }^{18}$ Lestari, Ria Y, "Peran Kegiatan Ekstrakurikuler Dalam Mengembangkan Watak Kewarganegaraan Peserta Didik”, Untirta Civic Education Journal, Vol. 1, No. 2 (Desember 2016), 136-152.

${ }^{19}$ Kristianto, Aprilia Aji, dan Fitriana, Wedi, "Latihan Kepemimpinan Melalui Kegiatan Ekstrakurikuler Pramuka”, Jurnal Comm-Edu, Vol. 2, No. 2 (Mei 2019), 108-12.
} 
b. Mandiri, kegiatan pramuka dapat membentuk dan melatih siswa agar dapat melakukan segala sesuatu (kebutuhan) dengan mandiri seperti dapat menyiapkan buku pelajaran sendiri, membeli peralatan belajar sendiri, dan lain sebagainya. Ciri orang yang sudah mandiri adalah independen yaitu suatu kondisi dimana seseorang sudah tidak memerlukan arahan dari orang lain dan tidak bergantung kepada orang lain, dimana orang yang sudah memiliki independensi dapat dapat mengurus dan menyelesaikan masalah pada dirinya sendiri. ${ }^{20}$

c. Pemecahan masalah, siswa dilatih untuk dapat memecahkan berbagai masalah yang terjadi pada lingkungan sekitar seperti memecahkan masalah yang terjadi pada lingkungan belajar, keluarga, atau masyarakat. Pemecahan masalah diartikan sebagai suatu proses yang dilakukan seseorang untuk menjawab dan mengatasi berbagai permasalahan serta kesulitan yang dihadapinya hingga tujuan yang diinginkan dari proses tersebut tercapai. ${ }^{21}$

d. Dekat dan mencintai alam, pramuka secara tidak langsung akan membentuk pribadi siswa bagaimana cara mencintai, memanfaatkan, dan menjaga alam sekitar. Pembelajaran penjelajahan alam dilakukan dengan tujuan agar siswa dapat mengetahui secara langsung kondisi alam atau lingkungan sekitar, sehingga siswa dapat memiliki pengatahuan dan pengalaman yang nyata akan lingkungan serta dapat menentukan sikap terdapat lingkungan di sekitarnya. ${ }^{22}$

\footnotetext{
${ }^{20}$ Nasution, Toni, “Kemandirian Siswa dan Pendidikan Karakter”, Ijtimaiyah, Vol. 2, No. 1 (Januari-Juni 2018), 1-18.

${ }^{21}$ Sumartini, Tina Sri, "Peningkatan Kemampuan Pemecahan Masalah Matematis Siswa Melalui Pembelajaran Berbasis Masalah”, Jurnal Mosharafa, Vol. 5, No. 2 (Mei 2016), 148-158.

${ }^{22}$ Ardianti, Sekar Dwi, Savitri Wanabuliandari, dan Susilo Raharjo, "Peningkatan Perilaku Peduli Lingkungan dan Tanggung jawab Siswa melalui Model Ejas dengan Pendekatan Science Edutainment”, Jurnal Pendidikan Dasar, Vol. 4, No. 1 (Januari 2017), 1.
} 


\section{Leadership Latihan Dasar Kepemimpinan Siswa (LDKS)}

Merupakan program pendidikan yang diberikan untuk menyiapkan kader-kader siswa agar memiliki dan melatih jiwa kepemimpinan pada diri siswa. Karakter yang dibentuk dari kegiatan ini antara lain:

a. Jiwa pemimpin, ekstrakurikuler Latihan Dasar Kepemimpinan Siswa (LDKS) pada hakekatnya adalah untuk melatih dasar-dasar kepemimpinan kepada siswa agar dapat menjadi seorang pemimpin yang baik khususnya bagi dirinya sendiri, keluarga, sekolah, dan masyarakat. Manfaat kegiatan LDKS adalah menumbuhkan jiwa kepemimpinan pada diri siswa, sehingga siswa mampu mengatur dan mengelola kebutuhan dan permasalahan yang ada pada dirinya atau pada lingkungan sekitarnya. $^{23}$

b. Tanggung jawab, dengan LDKS dapat membentuk siswa untuk memiliki rasa bertanggung jawab yang tinggi terhadap tugas atau pekerjaan yang dihadapi siswa (dalam hal ini bertanggung jawab pada proses pendidikan di sekolah). Tanggung jawab merupakan sikap dan perilaku seseorang untuk mengerjakan dan menyelesaikan tugas dan tanggung jawabnya terhadap diri sendiri, lingkungan, masyarakat, negara, dan bahkan tugas dan tangung jawab dari Tuhan YME yang telah diberikan kepada dirinya. $^{24}$

c. Mampu membuat keputusan berdasarkan pada pertimbangan dan pemikiran yang tepat sesuai dengan norma sosial dan norma agama. Pengambilan keputusan adalah cara atau pola pikir yang dilakukan oleh individu untuk menilai berbagai pilihan jawaban atau alternatif pemecahan masalah yang ada sehingga individu tersebut mampu

\footnotetext{
${ }^{23}$ Aprianti, Rina, dan Wahyunisngsih, Tri, "Pelaksanaan Kegiatan Latihan Dasar Kepemimpinan sebagai Wahana Membentuk Jiwa Kepemimpinan Siswa (Studi Kasus di OSIS SMKN 1 Yogyakarta Periode 2012-2013)”, Jurnal Citizenship, Vol. 3, No. 2 (Januari 2014), 127-140, [https://doi.org/10.12928/citizenship.v3i2.10675].

${ }^{24}$ Nofianti, Ira, Umi Chotimah, dan Emil El Faisal, "Pemerolehan Nilai-Nilai Tanggung jawab Siswa Kelas XI melalui Kegiatan Ekstrakurikuler Pramuka (Studi Kasus di SMA Negeri 1 Gelumbuang)”, Jurnal Bhineka Tunggal Ika, Vol. 03, No. 01 (Mei 2016), 53-64.
} 
memilih, memutuskan, dan menggunakan satu alternatif sesuai dengan yang dikehendakinya. ${ }^{25}$

\section{Pencak Silat}

Kegiatan ektrakurikuler yang dilakukan untuk melatih keahlian bela diri siswa. Karakter yang dibentuk dari kegiatan ini adalah:

a. Ketangguhan, pencak silat dapat melatih ketangguhan fisik siswa sehingga mereka dapat lebih siap dan sigap dalam menghadapi kehidupan, khususnya Tangguh dalam menghadapi proses pembelajaran di sekolah. Ketangguhan atau hardiness merupakan suatu sifat atau kepribadian seseorang yang dapat dilatih, dikembangkan, dan dipelajari dalam kondisi tertentu agar bermanfaat bagi kehidupannya. ${ }^{26}$

b. Kecakapan, kecapakan diartikan sebagai kemampuan menguasai berbagai jurus untuk mempertahankan diri yang dapat digunakan oleh siswa dalam hal-hal yang positif. Kecakapan merupakan kemampuan yang dimiliki oleh siswa untuk memahami dan menguasai suatu keterampilan tertentu. $^{27}$

\section{Melukis}

Kegiatan memindahkan objek yang dilihat oleh seseorang kedalam sebuah kertas atau kanvas gambar. Karakter yang ingin dibentuk dari kegiatan ini adalah:

a. Detail, dengan melukis siswa dapat menuangkan suatu (objek yang dilihat) secara detail atau terperinci ke dalam kanvas atau kertas. Hal ini secara tidak langsung akan melatih ketelitian dan kecermatan siswa dengan baik, sehingga siswa dapat memanfaatkan ketelitian dan

\footnotetext{
${ }^{25}$ Rofiq, Arif Ainur, "Pentingnya Keterampilan Pengambilan Keputusan Sosial Bagi Siswa SMP”, Psympatic: Ilmiah Psikologi, Vol. 02, No. 02 (Juni 2015), 175-184, [https://doi.org/10.15575/psy.v2i2.458].

${ }^{26}$ Wisudawati, Winy Nila, Riana Sahrani, dan Rahmah Hastuti, "Efektivitas Pelatihan Ketangguhan (Hardness) Untuk Meningkatkan Motivasi Berprestasi Akademik Siswa Atlet (Studi Pada Sekolah X di Tangerang)",Provite: Psikologi Pendidikan, Vol. 10, No. 2 (Januari 2017), 1-20.

${ }^{27}$ Yusria, "Peningkatan Kecakapan Personal Melalui Pembelajaran Kontekstual", Jurnal Pendidikan Usia Dini, Vol. 10, No. 02, (November 2016), 327-348.
} 
kecermatan tersebut pada proses pembelajaran. Ketelitian merupakan ciri kepribadian dari seseorang yang digunakan untuk mengidentifikasi derajat perbedaan seseorang dengan yang lain dalam suatu organisasi. ${ }^{28}$ Ketelitian dan kecermatan dilakukan dengan tujuan agar dapat membuat dan menentukan solusi yang tepat pada permasalahan yang sedang dihadapi. $^{29}$

b. Fokus, dengan melukis dapat melatih siswa tentang fokus pada suatu kegiatan yang sedang atau akan dijalani oleh seseorang (siswa). Diharapkan dampak dari fokus ini adalah siswa dapat berkonsentrasi pada proses proses pembelajaran dengan baik. Konsentrasi belajar merupakan kegiatan memusatkan atau menfokuskan perhatian pada proses belajar mengajar. ${ }^{30}$

c. Kreatif, dengan melukis siswa dapat mendeskripsikan tentang objek yang mereka lihat sesuai dengan pola pikir dan imajinasi siswa. Sehingga diharapkan siswa memiliki kreativitas dalam menjalankan tugasnya sebagai pelajar sehingga memiliki nilai manfaat yang tinggi bagi dirinya sendiri, sekolah, keluarga, dan masyarakat. Kreatif merupakan kemampuan yang digambarkan dengan kelancaran, keluwesan, dan cara berfikir yang orisinil dari seseorang dalam menggabungkan suatu konsep dengan konsep yang lain. ${ }^{31}$

\footnotetext{
${ }^{28}$ Dayanti, Ria Wulan, "Pengaruh Komunikasi Interpersonal, Ketelitian (Conscientiousness) dan Kepuasan Kerja Terhadap Kinerja Kepala Sekolah PAUD di Medan Deli”, Jurnal Pendidikan Dan Pengawasan, Vol. 2, No. 2 (Oktober 2014), 55-70.

${ }^{29}$ Yudha, Firma, "Peran Pendidikan Matematika dalam Meningkatkan Sumber Daya Manusia Guna Membangun Masyarakat Islam Modern”, Jurnal Pendidikan Matematika, Vol. 5, No. 2 (Agustus 2019), 87-94.

${ }^{30}$ Setyani, Mutia, Rahma, dan Ismah, "Analisis Tingkat Konsentrasi Belajar Siswa dalam Proses Pembelajaran Matematika Ditinjau dari Hasil Belajar", Pendidikan Matematika, Vol. 01, (Oktober 2018), 73-84.

${ }^{31}$ Kenedi, "Pengembangan Kreativitas Siswa dalam Proses Pembelajaran di Kelas II SMP Negeri 3 Rokan IV Koto", Jurnal Ilmu Pendidikan Sosial, Sains dan Humaniora, Vol. 3, No. 2 (Juni 2017), 329-348.
} 


\section{Mengaji}

Program kegiatan mengaji merupakan kegiatan membaca kitab suci Al-Qur'an dengan baik dan benar. Karakter yang ditanamkan dari kegiatan ini adalah:

a. Menambah keimanan dan ketaqwaan siswa kepada Allah SWT. Mengaji adalah kewajiban seluruh umat muslim di dunia, untuk menunaikan kewajiban tersebut sekolah memberikan kegiatan kestrakurikuler mengaji Al-Qur'an dengan tujuan menambah keimanan dan ketaqwaan siswa kepada Allah SWT. Keimanan merupakan kepercayaan atau keyakinan dari seseorang dengan sepenuh hati kepada ajaran agama Islam yang meliputi yakin kepada Allah, malaikat, rosul, kitab, Qada dan Qadar, serta hari akhir yang telah ditetapkan oleh Allah SWT. ${ }^{32}$

b. Akhlak (sopan santun) siswa, dengan mengaji secara tidak langsung akan membentuk karakter siswa yang berakhlaq. Mengaji dilakukan dengan membaca dan menjelaskan arti ayat Al-Qur'an kepada siswa yang dapat membentuk akhlaq siswa yaitu ber-akhlaqul karimah. Akhlak adalah tingkah laku (perkataan dan/atau perbuatan) yang ditampilkan oleh seseorang karena dorongan dari ajaran Allah SWT. ${ }^{33}$

c. Ketertiban, ketertiban diartikan sebagai cara membaca Al-Qur'an yang baik dan benar. Membaca Al-Qur'an tidak dilakukan dengan begitu, tetapi terdapat beberapa aturan sesuai dengan tajwid (hukum membaca AL-Qur'an) yang wajib diaplikasikan oleh siswa setiap membaca AlQur'an. Tajwid adalah cara memngeluarkan huruf dan cara membaca AlQur'an sesuai dengan makhraj dengan tujuan menghindari kesalahan dalam mengucapkan huruf atau bacaan dalam Al-Qur'an. ${ }^{34}$

\footnotetext{
${ }^{32}$ Shodiq, "Pengukuran Keimanan: Perspektif Psikologi”, Jurnal Pendidikan Islam, Vol. 8, No. 1 (April 2014), 125-138.

${ }^{33}$ Habibah, Syarifah, “Akhlak dan Etika dalam Islam”, Jurnal Pesona Dasar, Vol 1, No. 4 (Oktober 2015), 73

${ }^{34}$ Sudiarjo, Aso, Mariana, Arni Retno, dan Wahyu Nurhidayat, "Aplikasi Pembelajaran Ilmu Tajwid, Waqaf dan Makharijul Huruf Berbasis Android”, Jurnal Sisfotek Global, Vol. 5, No. 2 (September 2015), 54.
} 


\section{Dai Cilik}

Program Dai Cilik adalah karakter yang dibentuk dari kegiatan ekstrakurikuler ini adalah:

a. Menambah keimana dan ketaqwaan kepada Allah SWT, Da'i adalah menyampaikan kalam Allah kepada orang lain. Maka secara tidak langsung kegiatan ini akan menambah rasa keimanan dan ketaqwaan kepada Allah SWT. Meyakini wujud dan kebesaran dari Allah SWT dan meyakini firman Allah SWT merupakan cermin dari sikap beriman seseorang. ${ }^{35}$

b. Keberanian, kegiatan ini bertujuan melatih keberanian siswa untuk menyampaikan ajaran agama melalui kegiatan tatap muka baik secara langsung atau tidak langsung dengan orang lain. Keberanian membuat seseorang dapat menghadapi berbagai kesulitan atau situasi yang menakutkan sehingga seseorang dapat memahami apa yang sedang terjadi dan memutuskan apa yang akan dilakukan untuk mengatasi sitausi atau keadaan yang menegangkan. ${ }^{36}$

c. Kemampuan berfikir positif seorang Dai dapat membentuk seseorang untuk berfikir positif karena apa yang mereka sampaikan berlandaskan pada ajaran agama Islam yang merupakan pedoman dan panduan hidup bagi seluruh umat muslim. Berfikir positif merupakan kemampuan seseorang dalam menilai sesuatu dari sisi positif, sehingga seseorng dapat membentuk kemampuan dan kebiasaan seseorang dalam menilai sesuatu dari sisi positifnya. ${ }^{37}$

d. Cakap berkomunikasi, seorang Dai harus dapat melakukan komunikasi yang sangat baik dengan orang lain. Aspek komunikasi dalam Dai antara lain adalah intonasi, artikulasi, serta mimik saat melakukan komunikasi

\footnotetext{
${ }^{35}$ Habibah, Syarifah, “Akhlak dan Etika dalam Islam”, Jurnal Pesona Dasar, Vol. 1, No. 4 (Oktober 2015), 73.

${ }^{36}$ Garmo, J, Pengembangan Karakter Untuk Anak, (Jakarta: Kasaint Blanc, 2013), 116.

${ }^{37}$ Anggraini, Yeni, Syaf, Auliya, dan Adri Murni, "Hubungan Antara Berfikir Positif Dengan Kecemasan Komunikasi pada Mahasiswa”, Psycopolytan (Jurnal Psikologi), Vol. 1, No. 1 (Agustus 2017), 31.
} 
dengan orang lain agar apa yang disampaikan dapat didengarkan dan tersampaikan dengan baik kepada orang lain. Komunikasi yang efektif dicirikan dengan pengertian, menimbulkan kesenangan, mempengaruhi sikap orang lain, meningkatkan hubungan sosial dengan orang lain, serta dapat menimbulkan Tindakan dari orang lain. ${ }^{38}$

e. Mempengaruhi orang lain, Dai adalah kegiatan mengkomunikasikan dan menyampaikan kalam Allah dengan harapan orang yang sedang mendengarkan dapat diajakuntuk mengikuti jalan dan aturan yang datang dari Allah SWT. Dakwah merupakan kegiatan untuk mempengaruhi dan mengajak orang lain kepada jalan kebaikan dan melarang pada jalan keburukan yang sesuai dengan prinsip agama Islam yaitu mencapai kebahagiaan dunia dan akhirat. ${ }^{39}$

\section{SIMPULAN}

Penelitian tentang penanaman karakter pada siswa melalui kegiatan intrakurikuler dan ekstrakurikuler di sekolah sangat berdampak pada pembentukan karakter siswa baik di sekolah ataupun di luar lingkungan sekolah (seperti lingkungan keluarga dan masyarakat). Sehingga dengan adanya penelitian ini, diharapkan dapat memberikan masukan dan menjadi bahan rujukan yang baik bagi sekolah lain yang ingin mengembangkan cara mengimplementasikan pendidikan karakter di sekolah. Hasil penelitian menunjukkan terlalu banyak kegiatan ekstrakurikuler yang diberlakukan oleh sekolah sehingga memungkinkan terjadinya kejenuhan belajar pada diri siswa. Diharapkan pada penelitian berikutnya, peneliti dapat mengungkapkan cara yang efektif dan efisien dalam mengimplementasikan pendidikan karakter di sekolah.

\footnotetext{
${ }^{38}$ Suprapto, Hugo Aries, "Pengaruh Komunikasi Efektif Untuk Meningkatkan Hasil Bekajar Mahasiswa”, Jurnal Ilmiah Kependidikan, Vol. XI, No. 1 (September 2017), 13.

${ }^{39}$ Zulkarnaini, "Dakwah Islam di Era Modern", Jurnal Risalah, Vol. 26, No. 3 (September 2015), 151.
} 


\section{DAFTAR PUSTAKA}

Anggraini Yeni, Syaf, Auliya, dan Adri Murni. "Hubungan Antara Berfikir Positif Dengan Kecemasan Komunikasi pada Mahasiswa", Psycopolytan (Jurnal Psikologi), Vol. 1, No. 1 Agustus 2017.

Apriani, Rina, dan Wahyuningsih, Tri. "Pelaksanaan Kegiatan Latihan Dasar Kepemimpinan Sebagai Wahana Membentuk Jiwa Kepemimpinan Siswa (Studi Kasus di OSIS SMKN 1 Yogyakarta Periode 2012-2013)", Jurnal Citizenship, Vol. 3, No. 2 Januari 2014.

Ardianti, Sekar Dwi, Savitri Wanabuliandari, dan Susilo Raharjo. "Peningkatan Perilaku Peduli Lingkungan dan Tanggung jawab Siswa melalui Model Ejas dengan Pendekatan Science Edutainment", Jurnal Pendidikan Dasar, Vol 4, No. 1 Januari 2017.

Asmani, J. Buku Panduan Internalisasi Pendidikan Karakter di Sekolah. Yogyakarta: Diva Pers, 2011.

Badawi. "Pendidikan Karakter dalam Pembentukan Akhlak Mulia di Sekolah", Ilmu Pendidikan, Oktober 2019.

Baidowi, Achmad. "Implementasi Kebijakan Program Bantuan Operasional Penyelenggaraan Pendidikan Pada Masa Pandemi Covid-19”, Jambura Journal of Educational Management, Vol. 1, No. 2 September 2020.

Citra, Yulia. "Pelaksanaan Pendidikan Karakter dalam Pembelajaran", Jurnal Penelitian Pendidikan Khusus, Vol 1, No. 1 Januari 2012.

Dayanti, Ria Wulan. "Pengaruh Komunikasi Interpersonal, Ketelitian (Conscintiousness) dan Kepuasan Kerja Terhadap Kinerja Kepala Sekolah PAUD di Medan Deli", Jurnal Pendidikan dan Pengawasan, Vol. 2, No. 2 Oktober 2014.

Garmo, J. Pengembangan Karakter Untuk Anak. Jakarta: Kasaint Blanc, 2013.

Habibah, Syarifah. "Akhlak dan Etika dalam Islam", Jurnal Pesona Dasar, Vol. 1, No. 4 Oktober 2015.

Kenedi. "Pengembangan Kreativitas Siswa dalam Proses Pembelajaran di Kelas II SMP Negeri 3 Rokan IV Koto", Jurnal Ilmu Pendidikan Sosial, Sains, dan Humaniora, Vol. 3, No. 2 Juni 2017.

Kesuma, Dharma, Triatna, Cepi, dan Permana Johar. Pendidikan Karakter: Kajian Teori dan Praktik di Sekolah. Bandung: Remaja Rosdakarya, 2011.

Kristianto, Aprilia Aji, dan Fina, Wedi. "Latihan Kepemimpinan Melalui Kegiatan Ekstrakurikuler Pramuka”, Jurnal Comm-Edu, Vol. 2, No. 
2 Mei 2019.

Lestari, Ria Yuni. "Peran Kegiatan Ekstrakurikuler dalam Mengembangkan Watak Kewarganegaraan Peserta Didik", Untirta Civic Education Journal, Vol. 1, No. 2 Desember 2016.

Maunah, Binti. "Implementasi Pendidikan Karakter dalam Pembentukan Kepribadian Holistik Siswa", Jurnal Pendidikan Karakter, Vol. v, No. 1, 2015.

Nasution, Toni."Kemandirian Siswa dan Pendidikan Karakter", Ijtimaiyah, Vol. 2, No. 1 Januari-Juni 2018.

Nofianti, Ira, Umi Chotimah, dan Emil El Faisal."Pemerolehan Nilai-Nilai Tanggung jawab Siswa Kelas XI melalui Kegiatan Ekstrakurikuler Pramuka (Studi Kasus di SMA Negeri 1 Selumbung)", Jurnal Bhineka Tunggal Ika, Vol. 3, No. 1 Mei 2016.

Omeri, Nopan. "Pentingnya Pendidikan Karakter dalam Dunia Pendidikan", Jurnal Manajer Pendidikan, Vol. 9, No 3 Juli 2015.

Peraturan Presiden Republik Indonesia Nomor 87 Tahun 2017 tentang Penguatan Pendidikan Karakter.

Rofiq, Arif Ainur. "Pentingnya Keterampilan Pengambilan Keputusan Sosial Bagi Siswa SMP", Psympathic: Jurnal Ilmiah Psikologi, Vol. 2, No. 2 Juni 2015.

Satori, P., dan Komariah, A. Metodologi Penelitian Kualitatif. Bandung: Alfabeta, 2010.

Setyani, Mutia Rahma, dan Ismah. "Analisis Tingkat Konsentrasi Belajar Siswa Dalam Proses Pembelejaran Matematika Ditinjau dari Hasil Belajar", Pendidikan Matematika. Vol. 1, Oktober 2018.

Shodiq. "Pengukuran Keimanan: Perspektif Psikologi", Jurnal Pendidikan Islam, Vol 8, No. 1 April 2014.

Sudiarjo, Aso, Mariana, Arni Retno, dan Wahyu Nurhidayat. "Aplikasi Pembelajaran Ilmu Tajwid, Waqaf dan Makharijul Huruf Berbasis Android", Jurnal Sisfotek Global, Vol. 5, No. 2 September 2015.

Sugiyono. Metode Penelitian Kuantitatif, Kualitatif, dan R\&D. Bandung: Alfabeta, 2011.

Sugiyono, Metode Penelitian Pendidikan: Pendekatan Kuantitatif, Kualitatif, dan R\&D. Bandung: ALfabeta, 2013.

Sumartini, Tina Sri. "Peningkatan Kemampuan Pemecahan Masalah Matematis Siswa Melalui Pembelajaran Berbasis Masalah", Jurnal Mosharafa, Vol. 5, No. 2 Mei 2016.

Suprapto, Huga Aries. "Pengaruh Komunikasi Efektif Untuk Meningkatkan 
Hasil Belajar Mahasiswa", Jurnal Ilmiah Kependidikan, Vol. XI, No. 1 September 2017.

Wisudawati, Winy Nila, Sahrani, Riana, dan Rahmah Hastuti. "Efektivitas Pelatihan Ketangguhan (Hardiness)Untuk Meningkatkan Motivasi Berprestasi Akademik Siswa Atlet (Studi Pada Sekolah X di Tangerang)", Provite Jurnal Psikologi Pendidikan, Vol. 10, No.2 Januari 2017.

Yudha, Firma. "Peran Pendidikan Matematika dalam Meningkatkan Sumber Daya Manusia Guna Membangun Masyarakat Islam Modern", Jurnal Pendidikan Matematika, Vol. 5, No. 2 Agustus 2019.

Yusria. "Peningkatan Kecakapan Personal Melalui Pembelajaran Kontekstual", Jurnal Pendidikan Usia Dini, Vol. 10, No. 2 November 2016.

Zulkarnaini. "Dakwah Islam di Era Modern", Jurnal Risalah, Vol. 26, No. 3 September 2015. 